\title{
Syntaxonomical analysis of sandy grassland vegetation dominated by Festuca vaginata and F. pseudovaginata in the Pannonian basin
}

\author{
Károly Penksza ${ }^{1}$, Péter Csontos ${ }^{2}$, Gergely Pápay ${ }^{1, *}$ (i)
}

Key words: coenotaxon, DanubeTisza Interfluve, degraded sandy grassland, diagnostic species.

Ključne besede: cenotakson, ozemlje med Donavo in Tiso, degradirana peščena travišča, diagnostične vrste.

Received: 29. 01. 2019

Revision received: 27. 10. 2020

Accepted: 03. 12. 2020

Co-ordinating Editor:

Orsolya Valkó

\begin{abstract}
Festucetum vaginatae Rapaics ex Soó 1929 em. Borhidi 1996 is a characteristic association of the calcareous sandy areas of the Pannonian basin; its dominant grass species is Festuca vaginata. Another typical species of these sandy areas is the newly discovered $F$. pseudovaginata. The question is whether $F$. pseudovaginata forms an independent coenotaxa? Our study proved that $F$ vaginata and $F$. pseudovaginata populations grow separately and compose different associations. Stands dominated by $F$. pseudovaginata had a higher species richness and harboured twice as many Festuco-Brometea species compared to the Festucetum vaginatae stands. Diagnostic species of the Festucetum pseudovaginatae association are Festuca pseudovaginata, Colchicum arenarium, Ephedra distachya, Koeleria majoriflora, and Astragalus onobrychis. The number of species, the density of the individuals, and the variability and diversity of the vegetation separated it from the Festucetum vaginatae association; thus, it can be considered an independent endemic association. Festucetum pseudovaginatae has its own differentiating and dominant species: Carex stenophylla, Cynodon dactylon, Eryngium campestre, Kochia laniflora.
\end{abstract}

Izvleček

Festucetum vaginatae Rapaics ex Soó 1929 em. Borhidi 1996 je značilna asociacija na apneniških peščenih območjih v Panonski nižini; dominantna trava je Festuca vaginata. Druga značilna vrsta teh peščenih območij je novo odkrita vrsta $F$. pseudovaginata, za katero se pojavlja vprašanje, ali gradi tudi samostojne sintaksone. $Z$ našo raziskavo smo dokazali, da populacije vrst $F$. vaginata in F. pseudovaginata uspevajo ločeno in gradijo različne asociacije. Sestoji, v katerih prevladuje $F$. pseudovaginata so vrstno bogatejši in v njih se pojavlja dvakrat več vrst razreda Festuco-Brometea v primerjavi s sestoji Festucetum vaginatae. Diagnostične vrste asociacije Festucetum pseudovaginatae so: Festuca pseudovaginata, Colchicum arenarium, Ephedra distachya, Koeleria majoriflora in Astragalus onobrychis. Število vrst, gostota osebkov, variabilnost in raznolikost vegetacije jo jasno loči od asociacije Festucetum vaginatae, zato jo lahko obravnavamo kot samostojno endemično asociacijo. Festucetum pseudovaginatae označujejo lastne razlikovalne in dominantne vrste: Carex stenophylla, Cynodon dactylon, Eryngium campestre, Kochia laniflora.

\footnotetext{
1 Szent István University, Institute of Crop Production Sciences, H-2100 Gödöllő, Páter K. u. 1, Hungary

2 Institute for Soil Science and Agricultural Chemistry, Centre for Agricultural Research H-1022 Budapest, Herman O. út 15, Hungary

* Corresponding author: E-mail: geri.papay@gmail.com
} 


\section{Introduction}

Pannonic sandy grasslands are important habitats harbouring several endemic and rare plant species, included in the Natura 2000 network as 'Pannonic sand steppes' (habitat code: 6260). Festuca vaginata forms psammophytic communities on calcareous areas in the Pannonian basin. The alliance of Festucion vaginatae Soó 1929 occurs from the western shores of the Black Sea to the Pannonian Basin along the Danube valley, encompassing the Pontic and Pannonian regions. Festucetum vaginatae Rapaics ex Soó 1929 em. Borhidi 1996 is the most widespread indigenous association in this alliance.

Three associations of sandy grasslands occur in acidic sandy areas of the Pannonian region, of which Festuco dominii-Corynephoretum Borhidi (1958) 1996 (Borhidi et al. 2012) is the most widespread. Festuca dominii is considered to be the dominant species of this association, which is why it is named after this species. Festuco vaginatae-Corynephoretum Soó in Aszód 1935 is characteristic in the eastern parts of the Pannonian flora region (Nyírség), where Festuca vaginata is the dominant grass species. Achilleo ochroleucae - Corynephoretum (Hargitai 1940) Borhidi 1996 is found mainly in the middle sand dune range in the area between the Danube and Tisza rivers. The stands are dominated by the greyish tussocks of Corinephorus canescens forming and open and loose mat with $40-50 \%$ vegetation cover (Borhidi et al. 2012).

There are several taxonomic debates around Festuca species occurring in the Pannonian sandy grasslands. The currently valid classification of Festuca dominii Krajina is Festuca psammophila subsp. dominii (Krajina) P. Šmarda, which was clarified by Šmarda et al. (2007). Even though the basic species is missing from the Pannonian region (Penksza 2019), according to both the collected and the herbarium examples. Many of the examined Festuca vaginata individuals were found to have short (0.1)0.2-0.4 $\mathrm{mm}$ spikes on the glume, though this can be considered a variety of the $F$. vaginata species (Šmarda et al. 2007), which taxa do not have their own range.

Festuca pseudovaginata is a recently discovered fescue species of the Pannonian sandy grasslands (Penksza 2003). The distinctive features of $F$. pseudovaginata are the following (Figure 1). The stem is $20-35 \mathrm{~cm}$ high and hairless. The basal leaves are hairless, with a light green colour, they are not glaucous. The surface of base leaves is smooth. The base leaves have a continuous sclerenchyma ring. The sclerenchyma ring is extraordinarily thick, and not uniform in the side of the mesophyllum. In young leaves ragged sclerenchyma rings can also be observed. The awn on the outer lemma is $1.2-1.8 \mathrm{~mm}$ long. The locus classicus of this species is Kis-tece legelö (Kis-tece pasture) situated near Vácrátót, Hungary (Penksza 2003). Our preliminary examinations on the distribution and habitat characteristics of $F$. pseudovaginata performed by Szabó et al. (2017) revealed that the species prefers degraded habitats, which was also confirmed by the soil parameters of the studied populations. After the discovery of the species, our aim was to search systematically the Pannonian sandy regions to reveal new occurrences and to examine the plant community composition of the sandy grasslands where $F$. pseudovaginata occurs.

\section{Materials and Methods}

During the systematic sampling of sandy grasslands, Festuca specimens were collected at 20 sites in the Carpathian Basin. In this paper we present data from two sites: the Tece pasture near Vácrátót and from Szigetmonostor on Szentendre Island where both F. vaginata and F. pseudovaginata occurred.

The two examined areas are located in the northern part of the Danube-Tisza Interfluve, under similar abiotic conditions. The mean temperature in the coldest month (January) is $3{ }^{\circ} \mathrm{C}$, in the warmest month (July) $20.5^{\circ} \mathrm{C}$, the mean annual temperature is $9.5^{\circ} \mathrm{C}$. Precipitation is 550-600 mm (Péczely 2006). Due to the low precipitation and poor water-holding capacity of the soil, sites are characterized by an extremely dry and warm microclimate (Péczely 2006). The close surface geology of the Danube-Tisza Interfluve region is determined by mainly carbonatic eolian sediments of the Danube River. At the higher, dry landscape positions carbonatic shifting sands and humic sandy soils (Arenosols) can be found, which are characterized by unfavourable physical and chemical properties (high permeability and low water and nutrient storage capacity), thus have low fertility (Dövényi 2010, Stefanovits 2010).

The main difference between the two areas lies in landscape use and history. The pasture at Tece has been affected by continuous landscape transformation activities, including the cutting of the woody component of the forest steppe (Fekete et al. 1976). The area at Szigetmonostor on the Szentendre Island on the Danube has been being used similarly for centuries, i.e. pasturing on natural grasslands. The mosaic structure of the foreststeppe complexes were not affected, as pasturing has been typical on the grassland patches without deforestation (Böhm 2015).

In both sites, a series of $F$ vaginata and a series of $F$. pseudovaginata dominated plots were sampled. Coenological sampling was carried out in May-June and September 2018, we recorded the percentage cover of vascular plant species in quadrats of $2 \mathrm{~m} \times 2 \mathrm{~m}$. In total, 15 relevés 




Figure 1: Appearance of the two fescue taxa. A: Tussocks of $F$. pseudovaginata (left) and $F$. vaginata (right); B: inflorescence of $F$. pseudovaginata; C: inflorescence of $F$ vaginata). Photos: Dr. Károly Penksza

Slika 1: Izgled dveh vrst bilnic. A: Šopa F. pseudovaginata (levo) in F. vaginata (desno); B: socvetje F. pseudovaginata; C: socvetje $F$. vaginata). Fotografije: Dr. Károly Penksza. 
were recorded in the centre of the patches dominated by F. vaginata and 19 relevés in the $F$. pseudovaginata stands, resulting in a total of 34 relevés. Species names follow the nomenclature of Király (2009), phytosociological nomenclature follows Borhidi et al. (2012).

We used an agglomerative cluster analysis technique (SYN-TAX program package): a fusion algorithm was a combinatorial method (minimizing increase of variance) and the correlation was used as comparative function (Podani 1997). Calculations were performed in the SYNTAX IV program (Podani 2001). For comparing the species numbers of relevés in the different grassland types and sites, one way ANOVA and Tukey-Kramer Multiple Comparisons test as a post hoc test were used, since the raw data showed Gaussian distribution and fulfilled homoscedasticity test. Species numbers of the two grassland types was also compared by an unpaired t-test based on data merged according to the two sites. Differences were considered significant at $\mathrm{p}<0.01$ level. DCA ordination was used to visualize the species composition of the $F$. vaginata and $F$. pseudovaginata series in the two sites.

\section{Results}

A total of 69 vascular plants were recorded in the coenological samples in the Festuca pseudovaginata dominated grasslands. There were 25 species in grasslands where Festuca vaginata was dominant. As a result, there were significant differences in the species richness of the two grassland types. Analysis of variance followed by Tukey-Kramer test supported significant differences of average species numbers between all possible pairs of grassland types and study sites, except for the pair of F. vaginata (Tece) versus F. vaginata (Szigetmonostor). Comparison of the two grassland types' species numbers (regardless of study sites) showed a strong significant difference $\left(\mathrm{n}_{F \text { vag. }}=15, \mathrm{n}_{F \text { pseudovag. }}=19, \quad \operatorname{mean}_{F \text { vag. }}=13.9\right.$, mean $\left._{\text {F pseudovag }}=29.4, \mathrm{t}=8.789, \mathrm{p}<0.0001\right)$.

The description of the plant communities dominated by $F$. pseudovaginata are given below.

Association Festucetum pseudovaginatae ass. nova

hoc. loco (Table 2) holotype SzFp1

Diagnostic species for the association: Festuca pseudovaginata, Colchicum arenarium, Ephedra distachya, Koeleria majoriflora, Astragalus onobrychis

Constant species: Carex stenophylla, Cynodon dactylon, Eryngium campestre, Kochia laniflora

The species occurring both in F. vaginata and F. pseudovaginata grasslands were the ones typical in natural and semi-natural sandy grasslands. Of these, the species of Pannonian psammophytic grasslands (Festucion vaginatae Soó 1929): Arenaria serpyllifolia, Bromus squarrosus, Cen- taurea arenaria, Erysimum diffusum, Fumana procumbens and Koeleria glauca. The various species of Atlantic sandy grasslands (Corynephoretalia Klika 1934) were present in both types: Cerastium semidecandrum, Rumex acetosella, Veronica dillenii.

The species typical of arid and semi-arid rocky and steppe grasslands (Festuco-Brometea), were mostly found only in quadrats with F. psedovaginata (e.g. Alyssum alyssoides, Erophila verna, Hypericum perforatum, Phleum phleoides, Poa angustifolia and P. bulbosa). Carex liparicarpos, C. stenophylla (continental sand steppes - Festucetalia vaginatae or rupicolae species), Viola kitaibeliana and Thymus praecox (Festucetalia vaginatae \& valesiacae) were present only in Festuca pseudovaginata grasslands. In the more disturbed F. pseudovaginata grasslands in Tece, there was a large number of various ruderal plant species characteristic of Chenopodietea, Chenopodietea \& Secalietea, Secalietea, Aphanion, such as Ambrosia artemisiifolia, Anchusa officinalis, Anthemis austriaca, Apera spica-venti, Conyza canadensis, and with the dominance of Cynodon dactylon. These are well-separated in the classification (Figure 2). There is a clear separation between the two associations. The F vaginata group is more uniform, with F. pseudovaginata diverging at two higher levels of difference. This is also apparent in the DCA analysis (Figure 3).

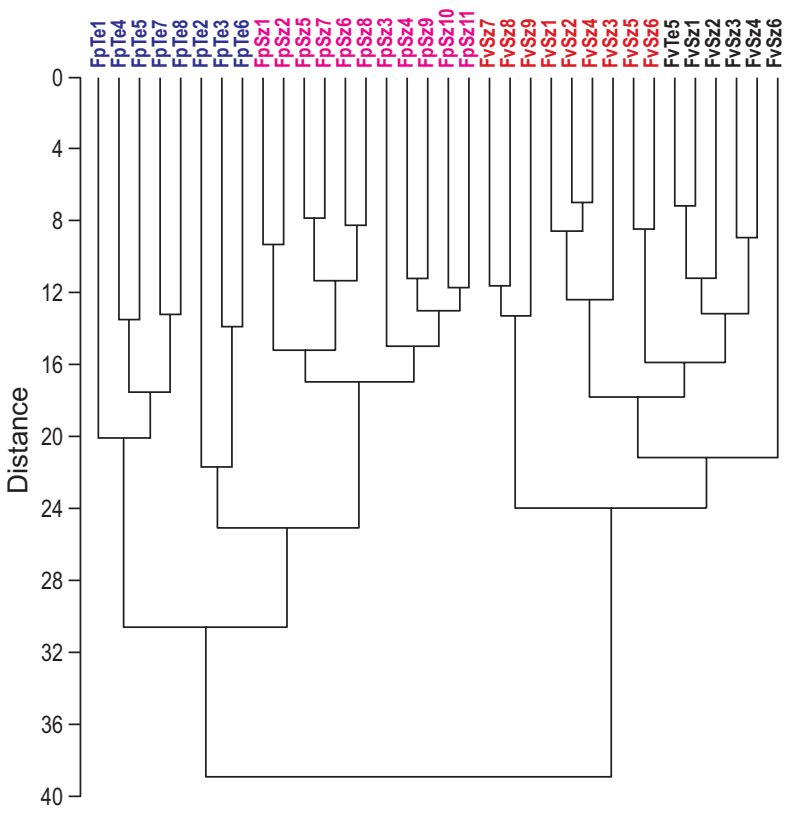

Figure 2: Classification of the sample areas. (FpTe: Festuca pseudovaginata series at Tece; FpSz: F. pseudovaginata series at Szigetmonostor; FvTe: F. vaginata series at Tece; FvSz: F. vaginata series at Szigetmonostor).

Slika 2: Klasifikacija vzorčenih območij (FpTe: serija Festuca pseudovaginata pri kraju Tece; FpSz: serija F. pseudovaginata pri kraju Szigetmonostor; FvTe: serija F. vaginata pri kraju Tece; FvSz: serija F. vaginata pri kraju Szigetmonostor) 


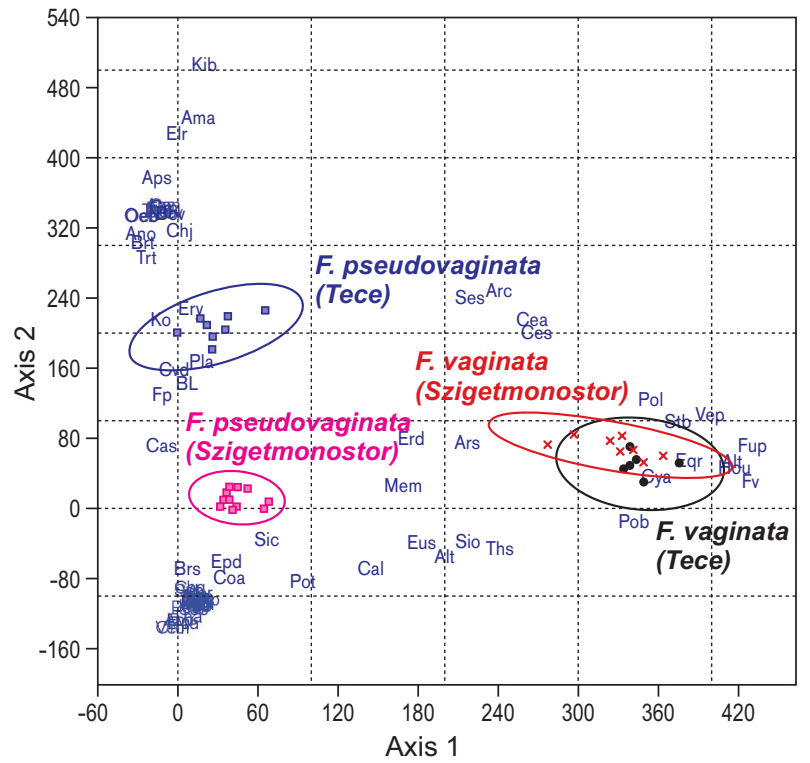

Figure 3: DCA analysis of the samples. The abbreviations of the species names are given in Appendix 1.

Slika 3: DCA analiza vzorcev. Okrajšave imen vrst so v Prilogi 1.

\section{Discussion}

Based on our results, we can refine the earlier conclusion of Borhidi et al. (2012) according to which the only dominant fescue species in Hungarian open sandy grasslands is $F$. vaginata. Our study shows that the species composition of grasslands dominated by Festuca vaginata and $F$. pseudovaginata is different. We have shown that both grassland types contain numerous species from the typical elements of the Festucion vaginatae, Festucetalia vaginatae \& valesiacae and rupicolae coenotaxa. The high abundance of Cynodon dactylon and the appearance of numerous species typical of ruderal vegetation types are a clear indication of the anthropogenic disturbances in areas colonised by $F$. pseudovaginata. Literature dealing with the effects of grazing confirms that dominance of Cynodon dactylon is often a consequence of high grazing pressure and is therefore can be used as an indicator of intensive grazing and trampling (Szentes et al. 2011, 2012, Deák et al. 2014).

We found no species indicating anthropogenic degradation in the $F$. vaginata type. In addition, in the $F$. vaginata stands a well-developed moss-lichen synusium occurred, which is also an indication of the good habitat quality. Contrary, in F. pseudovaginata grasslands we detected several disturbance-tolerant and weed species. Based on these results, it is likely that $F$. pseudovaginata grasslands appear as part of a regenerative process that starts after severe disturbances in the place of former for- ests; however, due to the ongoing smaller disturbances, they do not reach the state of equilibrium typical of natural habitats and this species composition retains its disturbed nature. Similarly, Borhidi et al. (2012) consider the Cynodonti-Festucetum pseudovinae Soó (in Aszód 1935) association description to be valid and confirm the role of grazing in the development of that association. This is another example for the formation of an association as a result of grazing that can be expected in the mosaic of complex forested habitats and treeless habitats prone to salinisation. These observations confirm our current results, namely that new associations may develop in the mosaic of woody and barren habitats as a result of grazing and disturbances of other origin, and that the appearance of brown forest soil can play a significant role in the separation of the two vegetation types (see also Szabó et al. 2017).

We assume that the two studied Festuca species are good indicators of the various soil types and of many properties of the topsoil (see also Bartha et al. 2004, 2008). Bajor et al. (2016) examined the effect of removing woody vegetation on the vegetation of open sandy grasslands. Their results show that after the removal of woody species, a large number of ephemeral species appears, similarly to old fallow land (Prach et al. 2007, Valkó et al. 2016) and spontaneously regenerating grasslands (Deák et al. 2015, Valkó et al. 2017). These species are replaced by perennials in the later phases of the successional progress (Török et al. 2009; Csecserits et al. 2011, Albert et al. 2014), primarily because perennials are probably better able to compete (Prach et al. 1997). According to Bajor et al. (2016), the most common perennial grass species after cutting of woody vegetation was F. pseudovaginata.

\section{Conclusions}

Festuca vaginata is the only dominant fescue species in both calcareous areas and acidic areas in the Pannonian region. However, we showed that the indigenous Festuca pseudovaginata also forms populations in the central sandy areas of the Carpathian Basin. The Festuca vaginata vegetation types hold many natural species and also show aspects of a composition containing spring and autumn annual or ephemeral plant species. The grasslands dominated by Festuca pseudovaginata show greater species richness and can be considered as an independent endemic biocenosis based on the number of species, the density of individuals, and the variability and diversity of the vegetation. 


\section{Acknowledgements}

The work was supported by OTKA K-125423. We acknowledge the general support of the Kiskunság National Park, the Duna-Ipoly National Park, the Fertö-Hanság National Park, Budapest Waterworks, The Mayor's Office, Budapest and 20430-3/2018/FEKUTSTRAT project. For P. C. the research was funded by the Széchenyi 2020 programme, the EU European Regional Development Fund and the Hungarian Government (GINOP-2.3.2-15-2016-00056).

Gergely Pápay (D) https://orcid.org/0000-0002-0321-3859

\section{References}

Albert, Á. J., Kelemen, A., Valkó, O., Miglécz, T., Csecserits, A., Rédei, T., Deák, B., Tóthmérész, B. \& Török, P. 2014: Trait-based analysis of spontaneous grassland recovery in sandy old-fields. Applied Vegetation Science 17: 214-224. DOI: https://doi.org/10.1111/avsc.12068

Bajor, Z., Zimmermann, Z., Szabó, G., Fehér, Z., Járdi, I., Lampert, R., Kerényi-Nagy, V., Penksza, P., L Szabó, Z., Székely, Z., Wichmann, B. \& Penksza, K. 2016: Effect of conservation management practices on sand grassland vegetation in Budapest, Hungary. Applied Ecology and Environmental Research 14 (3): 233-247. DOI: http://dx.doi. org/10.15666/aeer/1403_233247

Bartha, S., Campetella, G., Canullo, R., Bódis, J. \& Mucina, L. 2004: On the importance of fine-scale spatial complexity in vegetation restoration studies. International Journal of Ecology and Environmental Sciences 30: 101-116.

Bartha, S., Campetella, G., Ruprecht, E., Kun, A., Házi, J., Horváth, A., Virágh, K. \& Molnár, Z. 2008: Will interannual variability in sand grassland communities increase with climate change? Community Ecology 9(Suppl): 13-21. DOI: https://doi.org/10.1556/ComEc.9.2008.S.4

Böhm, É. I. 2015: A Szentendrei-sziget tájtörténete. (Landscape history of the Szentendre Island) [in Hungarian]. Private edition, 104 pp.

Borhidi, A., Kevey, B. \& Lendvai, G. 2012: Plant communities of Hungary. Akadémiai Kiadó, Budapest, 544 pp.

Csecserits, A. Czúcz, B., Halassy, M, Kröel-Dulay, G., Rédei, T., Szabó, R., Szitár, K. \& Török, K. 2011: Regeneration of sandy oldfields in the forest steppe region of Hungary. Plant Biosystems 145: 715-729. DOI: https://doi.org/10.1080/11263504.2011.601340

Deák, B., Valkó, O., Alexander, C., Mücke, W., Kania, A., Tamás, J. \& Heilmeier, H. 2014: Fine-scale vertical position as an indicator of vegetation in alkali grasslands Case study based on remotely sensed data. Flora 209: 693-697. DOI: https://doi.org/10.1016/j. flora.2014.09.005

Deák, B., Valkó, O., Török, P., Kelemen, A., Miglécz, T., Szabó, S., Szabó, G. \& Tóthmérész, B. 2015: Micro-topographic heterogeneity increases plant diversity in old stages of restored grasslands. Basic and Applied Ecology 16: 291-299. DOI: https://doi.org/10.1016/J. BAAE.2015.02.008

Dövényi Z. (ed.) 2010: Magyarország kistájainak katasztere. (Inventory of Microregions in Hungary) [in Hungarian] MTA Földrajztudományi Kutatóintézet, Budapest, 876 pp.

Fekete, G., Précsényi, I., Molnár, E. \& Melkó, E. 1976: Niche studies on some plant species of a grassland community. I. Comparison of various measurements. Acta Botanica Hungarica 22: 321-354.
Király, G. 2009: Új magyar füvészkönyv. Magyarország hajtásos növényei (New Hungarian Herbal. The Vascular Plants of Hungary. Identification Key) [in Hungarian]. Aggtelek National Park Directorate, Aggtelek, 616 pp.

Péczely, G. 2006: Éghajlattan (Climatology) [in Hungarian]. Nemzeti Tankönyvkiadó, Budapest, 336 pp.

Penksza, K. 2003: Festuca pseudovaginata, a new species from sandy areas of the Carpathian basin. Acta Botanica Hungarica 45: 356-372.

Penksza, K. 2019: Additions to the knowledge of Hungarian Festuca taxa I. Taxa of Festuca psammophila series in the Festuca vaginata species complex. Botanikai Közlemények 106(1): 65-70.

DOI: https://doi.org/10.17716/BotKozlem.2019.106.1.65

Podani, J. 1997: Syn-Tax 5.1: New version for PC and Macintosh computers. Coenoses 12: 149-152.

Podani, J. 2001: SYN-TAX IV. Computer programs for data analysis in ecology and systematics. in: Feoli, E. \& Orlóci, L. (eds.): Computer assisted vegetation analysis, Chapter 39: 437-452.

Prach, K., Lepš, J. \& Rejmánek, M. 2007: Old Field Succession in Central Europe: Local and Regional Patterns. In: Cramer, V. A., Hobbs, R. J. (eds.): Old fields: dynamics and restoration of abandoned farmland. Island Press, Washington, DC, pp. 180-202.

Prach, K., Pyšek, P. \& Šmilauer, P. 1997: Changes in species traits during succession: a search for pattern. Oikos 79: 201-205.

Šmarda, P., Šmerda, J., Knoll, A., Bureš, P. \& Danihelka, J. 2007: Revision of Central European taxa of Festuca ser. psammophilae Pawlus: morphometrical, karyological and AFLP analysis. Plant Systematics and Evolution 266: 197-232. DOI: https://doi.org/10.1007/s00606007-0532-3

Stefanovits, P. 2010: A tájak talajviszonyai. In: Stefanovits P., Filep Gy. \& Füleki Gy. Talajtan, Mezőgazda Kiadó, Budapest, 470 p.

Szabó, G., Zimmermann, Z., Catorci, A., Csontos, P., Wichmann, B., Szentes, S., Barczi, A. \& Penksza, K. 2017: Comparative study on grasslands dominated by Festuca vaginata and F. pseudovaginata in the Carpathian Basin. Tuexenia 37: 415-429.

DOI: https://doi.org/10.14471/2017.37.018

Szentes, S., Dannhauser, C., Coetzee, R. \& Penksza, K. 2011: Biomass productivity, nutrition content and botanical investigation of Hungarian Grey cattle pasture in Tapolca basin. Animal welfare, Etológia és Tartástechnológia 7(2): 180-198.

Szentes, S., Sutyinszki, Z., Szabó, G., Zimmermann, Z., Házi, J., Wichmann, B., Hufnágel, L., Penksza, K. \& Bartha, S. 2012: Grazed Pannonian grassland beta-diversity changes due to $C 4$ yellow bluestem. Central European Journal of Biology. 7(6): 1055-1065. DOI: https://doi.org/10.2478/s11535-012-0101-9

Török, P., Matus, G. \& Papp, M. 2009: Seed bank and vegetation development of sandy grasslands after goose breeding. Folia Geobotanica 44: 31-46. DOI: https://doi.org/10.1007/s12224-009-9027-z

Valkó, O., Deák, B., Török, P., Kelemen, A., Miglécz, T. \& Tóthmérész, B. 2017: Filling up the gaps - Passive restoration does work on linear landscape scars. Ecological Engineering 102: 501-508.

Valkó, O., Deák, B., Török, P., Kelemen, A., Miglécz, T., Tóth, K. \& Tóthmérész, B. 2016: Abandonment of croplands: problem or chance for grassland restoration? Case studies from Hungary. Ecosystem Health and Sustainability 2(2): e01208.

DOI: https://doi.org/10.1002/ehs2.1208 


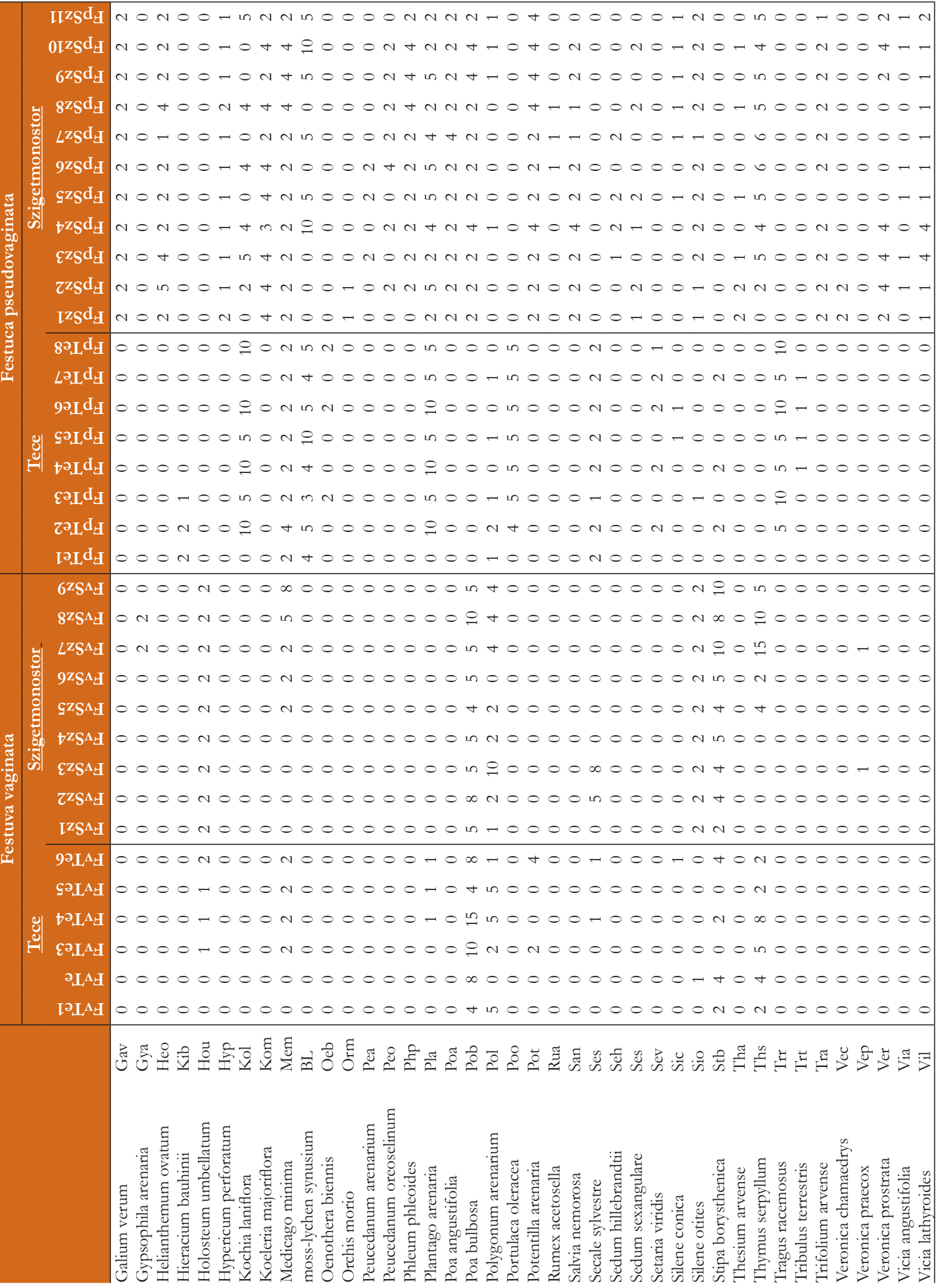

